\title{
Pro-Contra Of Marriage Age Restriction In Maqashid Syari'ah Perspective
}

\author{
Rifki Julian Wiranda*) and Akhmad Khisni ${ }^{* *}$ \\ *) Universitas Islam Sultan Agung (UNISSULA) Semarang,E-mail: \\ rifkijw mh36@std.unissula.ac.id \\ **) Faculty of Law, Universitas Islam Sultan Agung (UNISSULA) Semarang
}

\begin{abstract}
Efforts to prevent marriages that are considered underage are stated in the revision of the Marriage Law (UUP) in Act No. 16 of 2019 which equates the marriage age limit for men and women to nineteen years. The purpose of the research in this article is to find out how to limit the age of marriage and the suitability of the principle of benefit of the revision of the UUP in the review of Maqashid Syari'ah. The method used in this study is a normative juridical approach and empirical data as a complement. The results showed that the practice of marriage which was considered underage occurred because the community believed that a child who entered the age of puberty should be immediately married, because it was feared that it would cause widespread damage, such as masturbation, adultery or in other forms, namely phone sex.

Keywords: Maqashid Syari'ah; Marriage; Age Limit; Regulation; Children.
\end{abstract}

\section{Introduction}

Existentially, the position of sharia or Islamic law in Indonesian national law is a sub-system of national law itself as enshrined in the first Pancasila principle. Marriage is one of the laws that apply to men and women as creatures created in pairs. The marriage recommendation is determined based on the AlQuran, Sunnah and Ijma'.

Marriage is part of a noble character. Morals are fundamental in Islam, both morality to God, others as well as the natural surroundings. Well-known contemporary fiqh scholars mention several wisdoms of marriage, including to protect male and female humans from adultery, maintain human survival, maintain offspring and lineage, form families that are part of society, to hold mutual assistance between husband and wife creates love among the community and strengthens family ties and with marriage will also bring benefits and create a sense of responsibility. ${ }^{1}$

Efforts to prevent marriages assessed as child age are stated in the Constitutional Court Decision Number 22/PUU-XV/2017, dated December 13, 2018, in conjunction with the revision of the UUP which equalizes the marriage age limit for men and women, which is 19 years. ${ }^{2}$ Based on the provisions of Article 7 of the Marriage Law (UUP), if there is a deviation from the requirements for the age

\footnotetext{
${ }^{1}$ Nurhadi, "Maqashid Syari'ah Hukum Perkawinan Dalam Kompilasi Hukum Islam (KHI)," dalam AlFikra: Jurnal Ilmiah Keislaman, vol. 16, no. 2, (2017): hlm. 203-232. http://ejournal.uinsuska.ac.id/index.php/al-fikra/article/view/3831

2 Mahkamah Konstitusi, Putusan Mahkamah Konstitusi No. 22/PUU-XV/2017 (Indonesia, 2018), https://mkri.id/public/content/persidangan/putusan/22_PUU-XV_2017.pdf
} 
of marriage mentioned above, the marriage can only be held after receiving a dispensation from the court. The family is the smallest social sphere with a function to foster individuals as social beings. In addition, the family also has a plural function, namely providing material and spiritual welfare. ${ }^{3}$

This paper views that marriage is a complex issue, it is not enough to just look at it from one point of view. If it is related to the objectives of Islamic Law (Maqashid Syari'ah), at least there are four basic things that need to be considered in the reality of marriage, namely safety related to the purpose of maintaining religion (hifzhu ad-din), protection of the soul (hifzhu an-nafs), protection of reason (hifzhu al-aql) and protection of offspring (hifzhu annasl). Based on the description above, the research objectives are 1) To find out how to limit the age of marriage according to Maqashid Syari'ah; 2) To find out the suitability of the principle of benefit of the revision of the UUP in the review of Maqashid Syari'ah.

\section{Research Method}

The method used for this study uses a normative juridical approach and empirical data as a complement. The specifications of the research are qualitative research with data and data collection methods sourced from public policies relating to the limitation of the marriage age as referred to in Act No. 16 of 2019, the Compilation of Islamic Law and Maqashid Syari'ah Studies as well as the results of interviews with related parties in cases of implementing the Law. Law limiting the age of marriage which leads to a marriage dispensation in the Religious Courts. The method of analysis used refers to library research and interviews to find out and understand how the principle of benefit between the law and the perspective of Maqashid Syari'ah is matched.

\section{Results and Discussion}

\subsection{Restrictions on the Age of Marriage in the Perspective of Maqashid Syari'ah}

Islam does not recognize the age of marriage, anyone who is able to marry, regardless of age, can marry. Setting a certain age as a measure of the age of marriage is seen as against sunnatullah and such actions will actually increase free sex behavior even more, namely sexual disorders and disorders in society.

Although some parties do not agree with the policy that sets the age of marriage, in general there is a common view that people can only get married if they are able to get married. On the one hand we may agree that the ability getting married is a gift from Allah ta'ala, but on the other hand, there is a view that the policy of determining the age of marriage is contrary to Allah's law. ${ }^{4}$ Allah ta'ala

\footnotetext{
${ }^{3}$ Suratman, et.all., 2019, Hukum \& Kebijakan Publik, Bandung, Refika.

${ }^{4}$ Rio Satria, "Dispensasi Kawin Di Pengadilan Agama Pasca Revisi Undang-Undang Perkawinan" dalam Artikel Direktorat Jenderal Badan Pengadilan Agama (2019): p. 4-5. https://badilag.mahkamahagung.go.id/artikel/publikasi/artikel/dispensasi-kawin-di-pengadilanagama-pasca-revisi-undang-undang-perkawinan-oleh-rio-satria-16-10
} 
ordered in Surah An-Nur: 32-33 to the guardians to marry people under his guardianship, both male and female if they are able to marry. The act of the guardian preventing the person under his guardianship from getting married, even though he is able to fulfill the marriage obligations, is an act that is forbidden in Islamic law, because this action has the potential to cause slander (zina and seclusion or being alone between the opposite sex) in the midst of society.

Viewed from the point of view of Maqashid Syari'ah as the goal of Allah and His Messenger in formulating Islamic laws, marriage is proof of Allah's ihsan to His servants (jalbu al-mashalih wa dar'ul mafasid). ${ }^{5} \mathrm{Abu}$ Ishaq ash-Syatibi cites the research of scholars on the Qur'an and the Sunnah of the Prophet that it is prescribed for marriage and multiplying offspring to realize the benefit of mankind, both in this world and in the hereafter. If there is someone who wants to get married, while he is not able to fulfill the obligations of marriage, both material and non-material, then he must guard himself so as not to fall into actions that are contrary to Islamic law, while still trying to achieve the grace of Allah ta'ala to be able to marry.

In terminology, Mashlahah can be interpreted to take advantage and reject Madharat (danger) in order to maintain the purpose of syara' (Islamic law). ${ }^{6}$ The principle of Maqashid Syari'ah (the purpose of Islamic law) is directly proportional to the concept of maslahah, even the rules built by Maqashid Syari'ah are generally based on considerations of benefits (mashlahah). The purpose of syara' that must be maintained is to maintain religion, soul, mind, lineage and property. If someone performs an activity that is essentially to maintain the five aspects of the goals of syara', then it is called mashlahah. In addition, to reject all forms of harm (danger) related to the five objectives of syara', it is also called mashlahah.

Imam al-Ghazali views that a benefit must be in line with the goals of syara', even if it is contrary to human goals, because human benefit is not always based on the will of syari'a, but is often based on lust. Therefore, what is used as a benchmark in determining the benefit is the will and purpose of syara', not human will and goals. ${ }^{7}$

Some human actions lead to benefit, some lead to harm. The benefit or mafsadat produced is for the benefit of the world, the hereafter or for the benefit of the world and the hereafter. All the Syari'a that are ordered are for benefit, while all the Syari'a that are prohibited must contain mafsadat. Therefore, every benefit and harm has certain levels depending on the reward and harm that will be obtained. ${ }^{8}$

\footnotetext{
${ }^{5}$ Zulkayandri, "Konsep Ihsan 'Izz Al-Din Ibn Abd Al-Salam" dalam Al-Fikra: Jurnal Ilmiah Keislaman, vol. 4, no. 1 (2005): p. 31. http://ejournal.uin-suska.ac.id/index.php/al-fikra/article/view/3750

${ }^{6}$ Harun, "Pemikiran Najmudin At-Thufi Tentang Konsep Maslahah Sebagai Teori Istinbath Hukum Islam" in Jurnal Digital Ishraqi, vol. 5, no. 1 (2009): p. 24. https://publikasiilmiah.ums.ac.id/handle/11617/2276

7 Abu Hamid Al-Ghazali, 1980, Al-Mustashfa Min Ilmi Al-Ushul, Beirut, Darul Kutub al-Ilmiyah, p. 286.

8Izzuddin bin Abd Al-Salam, 1980, Qawa'id Al-Ahkam Fi Mashalih Al-Anam, Beirut, Darul Jail, Juz 1, p. 11.
} 
About a more concrete measure of benefit is explained by Abu Zahrah and Abdul Wahab Khalaf. If it is concluded then the requirements for the benefit are: ${ }^{9}$ The benefit must be in accordance with the maqaid ash-syari'ah, the spirit of the teachings, the arguments of kulli and the arguments of qath'i both wurud and dalalah.

- The benefit must be convincing, meaning that the benefit is based on careful and accurate research, so there is no doubt that it can bring benefits and avoid harm.

- Benefit brings convenience and does not bring difficulties beyond human capabilities.

- This benefit benefits the majority of the community, not a small number.

Wasilah or the way to get to the benefit has levels according to the purpose and benefit. Likewise, wasilah leading to mafsadat is also graded according to the level of mafsadat. Ibn Qoyyim al-Jauziyah mentions that all paths or wasilah that lead to benefit is called "Fath al-Zari'ah" (opening the way) and all wasilah that leads to mafsadat is called "Sadd al-Zari'ah" (closing the road). As for Shaykhul Islam Ibn Taimiyah, he detailed that the size of mafsadat and benefit is taken based on the Syari'a scales which include: ${ }^{10}$

- If there are more good things, then it is taken or ordered, even though the consequences are giving birth to a smaller mafsadat.

- If the bad deed is greater then the act must be prevented even if it eliminates the lesser ma'ruf act.

- If maslahat and mafsadat are balanced and interrelated, then neither is taken.

- As for the type, it is ordered to the absolute benefit and absolutely forbidden to the evil one.

Allah ta'ala also hints that the main function of marriage is to protect oneself from actions that are forbidden by Allah ta'ala, whether just approaching adultery or even doing it. ${ }^{11}$ The Prophet sallallaahu 'alaihi wasallam ordered his people to get married immediately for those who could afford it, not to delay. The Prophet sallallaahu 'alaihi wasallam said:

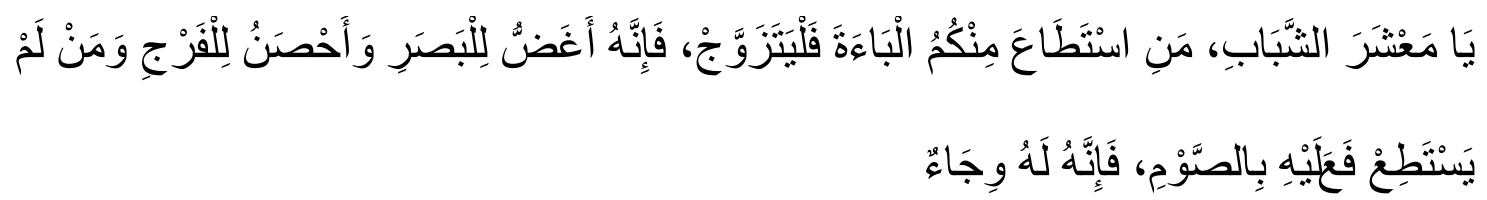

Translation: 0 youths, whoever of you is able to get married, hurry up, because marriage can protect the eyes and genitals, but for those who are not able to, let him fast, because fasting will protect himself. (Narrated by Bukhari and Muslim)

The hadith of the Prophet above also encourages young people who are able to get married to get married immediately. According to the opinion of the rajih (strongest) the most appropriate meaning of the word $a l-b a^{\prime} a h$ is financial ability. If he has not been able to fulfill his living as an obligation due to marriage, then he should fast because it can control his lust. Then the argument that discusses the

\footnotetext{
9 Ahmad Dzajuli, 2006, Kaidah-Kaidah Fikih, Jakarta, Kencana, p. 28-30.

10 Ibnu Taimiyah, t.t., Majmu' Al-Fatawa,Edition 28, p. 128-131.

11 Abdu al-Aziz ibnu Marzuq Ath-Tharifi, 1438, At-Tafsiru Wa Al-Bayanu Li Ahkami Al-Qurani, Riyadh, Maktabah Darul Minhaj Edition 4, p. 1859-1861.
} 
age of the prophet's wife who was a virgin when she married, the history of Hisham, from his father Urwah, that Aisha radhiyallahu 'anha narrates:

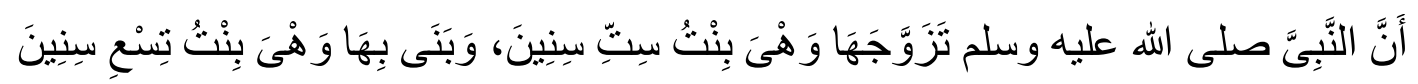

Translation: Indeed the Prophet sallallaahu 'alaihi wasallam married Aisyah when she was 6 years old, and he got together (biologically related) when Aisha was 9 years old..." (Narrated by Bukhari, 5134)

The hadith is a strong reference that Islamic law does not limit the age of marriage, this practice is exemplified directly by the Prophet Muhammad sallallaahu 'alaihi wasallam who married a virgin girl (not a widow), namely Ummul Mukminin Aisyah radhiyallahu 'anha at an age that is far from 16 or 19 years as the Revision of the Marriage Law.

\subsection{The Conformity of the Benefit Principle of the Revised UUP with Maqashid Syari'ah}

Act No. 1 of 1974 concerning Marriage states that marriage is an inner and outer bond between a man and a woman as husband and wife, with the aim of forming a happy and lasting household (family) based on the One Godhead. ${ }^{12}$

Article 7 paragraph (2) of the UUUP stipulates that in the case of deviations from the provisions on the age limit for marriage, parents can apply for dispensation to the court. Applications for dispensation for marriage are submitted voluntarily by parents and/or prospective brides who are considered not of sufficient age, both male and female. Applications for dispensation from marriage can be filed jointly. The Religious Courts can make a decision on the application for a marriage dispensation after hearing the statements of the parents, close family, or guardians of the child who will be granted a marriage dispensation. ${ }^{13}$

According to Soerjono Soekanto, a form of legal certainty is regulations from the central government that are generally accepted throughout the country. Another possibility is that the regulation is generally applicable, but for certain groups, it can also be local regulations, namely regulations made by local authorities that only apply in their area. ${ }^{14}$ According to Soedikno Mertokusumo, legal certainty is very much because it will make society more orderly. The law is tasked with creating legal certainty because it aims for public order. Without legal certainty, people do not know what to do, so that in the end there is unrest. However, if applied too extreme, it will be rigid and cause a sense of injustice. Laws are often considered cruel when tightened, lex dure, sed tamen scripta (Laws are cruel, but that's what they say). ${ }^{15}$

\footnotetext{
12 Achmad Budi W., "Implementation of Itsbat Nikah as A Way To Get The Legal Power Which Is Not Recorded" in Jurnal Daulat Hukum, vol. 1, no. 2 (2018): hlm. 517, http://jurnal.unissula.ac.id/index.php/RH/article/view/3325/2456.

13 Direktorat Jenderal Badan Peradilan Agama Mahkamah Agung Republik Indonesia, Pedoman Pelaksanaan Tugas \& Administrasi Peradilan Agama, Buku II), Jakarta, 2013. https://drive.google.com/file/d/1oh9oCracC9oaZ-waf80lTrX9vIflHjFB/view.

14 Soerjono Soekanto, 1974, Beberapa Permasalahan Hukum Dalam Kerangka Pembangunan Indonesia, Jakarta, UI Press.

15 Sudikno Mertokusumo, 1988, Mengenal Hukum, Yogyakarta, Liberty, p. 136.
} 
Legal certainty does not sanction someone who has a bad mental attitude, but sanctions against the manifestation of the bad mental attitude. One of the basic characteristics or character of Gustav Rrasbruce's goal is that legal certainty essentially has one meaning and is contained in justice and the usefulness of the law itself. ${ }^{16}$ However, in practice, if legal certainty is associated with justice, it will often be inconsistent with one another. This is because on the one hand it is not uncommon for legal certainty to ignore the principles of justice and vice versa, it is not uncommon for justice to ignore the principles of legal certainty. From what has been stated above, it is clear that legal certainty aims to create peace, comfort and order in society. If it is related to this research, the theory of legal certainty marks the basis for lawmakers to review public policies related to the age limit for marriage, considering the amount of mental damage and moral damage to the nation's children that will continue to occur due to sexual relations outside marriage.

According to the legislators, so that marriages do not end in a divorce, marriages between prospective husbands and wives who are underage must be prevented, because marriage has a relationship with population problems, so to limit the higher birth rate, marriages must be prevented between prospective husbands and wives who are still minors. Underage marriage or what is commonly referred to as early marriage is increasingly prevalent among Indonesian teenagers. The number of early marriages in Indonesia is relatively high at around $20 \%$ of the total number of marriages each year are marriages performed by couples who are less than 19 years old. ${ }^{17} \mathrm{~A}$ lower age limit for a woman to marry results in a higher birth rate, so limiting the age at marriage can be a solution to high birth rates. This is clearly contrary to the hadith of the Prophet who ordered his ummah to multiply offspring, even though multiplying offspring would also make the Prophet proud. He sallallaahu 'alaihi wasallam said:

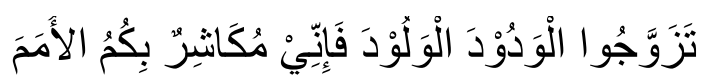

Meaning: "Marry a woman who loves and who can have many children (fertile \& young age), because indeed I will be proud of the cause (of) you in front of the previous people."18

Para fuqaha and statutory experts agree to stipulate that a person is held accountable for his actions and has the freedom to determine his life after he is of age or puberty. The signs are when it has issued semen for men and when it has menstruated or can get pregnant for women. The start of the legal age of puberty can vary from one person to another, due to environmental, geographical and so on. The initial limit for starting puberty legally is when a person is 12 years old for a boy and 9 years old for a girl.

${ }^{16}$ Rofi'atun, Rozihan \& Akhmad Khisni, "Civil Rights Of Children Outside Married Due Isbat Nikah Of Polygamy" in Jurnal Daulat Hukum, vol. 2, no. 4 (2019): hlm. 622, http://jurnal.unissula.ac.id/index.php/RH/article/view/8377.

17 Munsharif Abdul Chalim, Samsul Arifin \& Akhmad Khisni, "The Limit Of Age Of Marriage Is Related To The Certification Of Marriage" in Jurnal Daulat Hukum vol. 3, no. 2 (2020): hlm. 292, http://jurnal.unissula.ac.id/index.php/RH/article/view/10084/4157.

18 Abdul Hakim bin Amir Abdat, 2002, Menanti Buah Hati \& Hadiah Untuk Yang Dinanti, Jakarta, Darul Qolam. 
According to some Hanafiyah scholars, that is when a person has reached the age of 15 years for both boys and girls. In general, around the age of 15 years, a person's intellectual abilities develop deep enough to know between good and bad and between useful and harmful, so that they can know the consequences that arise from their actions. Imam Malik, Imam Shafi'i and Imam Ahmad stated that the growth of armpit hair is proof of a person's puberty. ${ }^{19} \mathrm{As}$ for contemporary scholars such as Ibn Hazm, that the argument used to justify parents marrying off their daughters who are considered "underage" is the action of Abu Bakr As-Sidiq radhiyallahu 'anhu, even the Prophet sallallaahu 'alaihi wasallam when he was at home with Aisyah at the age of 9 years. . In addition, the age of puberty based on the condition of 'urf (habits) and the geographical aspect in each country is also different.

The Religious Courts in considering the dispensation of marriage include the objectives of Islamic Sharia (maqashidu syari'ah), both in terms of existence (janibu al-wujud) through the existence of orders, and in terms of their absence (janibu al-'adm) with prohibitions. ${ }^{20}$ Other impacts such as pregnancy out of wedlock are factors that often dominate marriage dispensations, because marriage dispensations are used as a bridge to cover the family's disgrace and also to prevent greater damage if the two people are not married. ${ }^{21}$ Getting married is the only remedy for young people's lust in particular and the maintenance of society in general. Marriage is not to be limited, but fostered or optimized through pre/postmarital training and education programs.

\section{Closing}

The two prospective brides and their families are obliged to prevent actions that are forbidden in Islamic law, especially the increasingly rapid development of social media today, in order to avoid unlawful acts in other forms, such as phone sex, diverting their pent-up desires to physical prostitution and online prostitution or encourage him to masturbate which of course can damage the mental and moral of the nation. The determination of the age limit for marriage does not match the customs of the Indonesian people. The age of marriage is also not limited and not regulated by syar'i arguments, but is reviewed based on 'urf (habits and needs) that apply in the community. The existence of a marriage dispensation is a special right for Muslims. Therefore, the effort to limit the age of marriage is not appropriate because delaying legal intercourse will actually cause slander for the prospective bride and the order of social life. The Religious Courts should support the achievement of marriage as a noble and holy goal of Islamic law (maqashidu syari'ah), for the realization of maintaining the safety of mind, soul, body, softening the heart, improving health and multiplying generations of Muslims. The policies

\footnotetext{
${ }^{19}$ Muhammad Jawad Mughniyah, 2012, Al-Fiqh 'Ala Al-Madzahib Al-Khamsah Terj. Masyukur A.B., Jakarta, Lentera.

${ }^{20}$ Abu Ishaq Ibrahim bin Musa bin Muhammad al-Lukhmi Asy-Syathibi, 1997, Al-Muwafaqat, AlMamlakah al-'Arabiyah as-Su'udiyah, Dar al-Affan.

21 Siti Muzazanah, Akhmad Khisni \& Rozihan, “Judge Consideration of Religious Court Of Blora on Application of Married Dispensation" in Jurnal Daulat Hukum, vol. 2, no. 4 (2019): hlm. 553, http://jurnal.unissula.ac.id/index.php/RH/article/view/8356/3898.
} 
implemented by decision makers must create something that has good value to the public. Every rule that has been set needs an evaluation of the consequences of the rule. It is natural for government policies to be conservative, that the existing habits of life in the midst of society are adequate, so that changes are no longer necessary. This is so that the balance between law, public policy and the principle of benefit can be achieved simultaneously.

\section{References}

\section{Journals:}

[1] Achmad Budi W., "Implementation of Itsbat Nikah as A Way To Get The Legal Power Which Is Not Recorded" in Jurnal Daulat Hukum, vol. 1, no. 2 (2018) http://jurnal.unissula.ac.id/index.php/RH/article/view/3325/2456.

[2] Harun, "Pemikiran Najmudin At-Thufi Tentang Konsep Maslahah Sebagai Teori Istinbath Hukum Islam" in Jurnal Digital Ishraqi, vol. 5, no. 1 (2009)

[3] Nurhadi, "Maqashid Syari'ah Hukum Perkawinan Dalam Kompilasi Hukum Islam (KHI)." Al-Fikra: Jurnal Ilmiah Keislaman, vol. 16, no. 2 (2017), http://ejournal.uin-suska.ac.id/index.php/al-fikra/article/view/3831

[4] Rio Satria, "Dispensasi Kawin Di Pengadilan Agama Pasca Revisi UndangUndang Perkawinan" dalam Artikel Direktorat Jenderal Badan Pengadilan Agama (2019). https://badilag.mahkamahagung.go.id/artikel/publikasi/artikel/dispensasikawin-di-pengadilan-agama-pasca-revisi-undang-undang-perkawinan-olehrio-satria-16-10

[5] Rofi'atun, Akhmad Khisni and Rozihan. "Civil Rights Of Children Outside Married Due Isbat Nikah Of Polygamy" in Jurnal Daulat Hukum, vol. 2, no. 4 (2019), http://jurnal.unissula.ac.id/index.php/RH/article/view/8377

[6] Samsul Arifin, Akhmad Khisni, \& Munsharif Abdul Chalim. "The Limit Of Age Of Marriage Is Related To The Certification Of Marriage" in Jurnal Daulat Hukum, vol. 3, no. 2020 ), http://jurnal.unissula.ac.id/index.php/RH/article/view/10084/4157

[7] Siti Muzazanah, Akhmad Khisni \& Rozihan. "Judge Consideration of Religious Court Of Blora on Application of Married Dispensation" in Jurnal Daulat

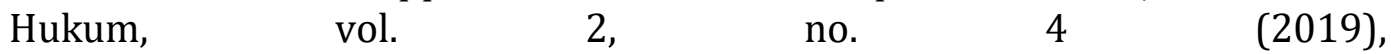
http://jurnal.unissula.ac.id/index.php/RH/article/view/8356/3898

[8] Zulkayandri. "Konsep Ihsan 'Izz Al-Din Ibn Abd Al-Salam" dalam Al-Fikra: Jurnal Ilmiah Keislaman, vol. 4, no. 1 (2005)

\section{Books:}

[1] Abdul Aziz ibnu Marzuq Ath-Tharifi, 1438, At-Tafsiru Wa Al-Bayanu Li Ahkami Al-Qurani. Riyadh, Maktabah Darul Minhaj.

[2] Abdul Hakim bin Amir Abdat, 2002, Menanti Buah Hati \& Hadiah Untuk Yang Dinanti, Jakarta, Darul Qolam.

[3] Abdul Khair, 2004, Hukum \& Penelitian Hukum, Bandung, Cipta Aditya Bakti.

[4] Ahmad Dzajuli, 2006, Kaidah-Kaidah Fikih, Jakarta, Kencana.

[5] Asy-Syathibi, 1997, Al-Muwafaqat, Arab Saudi, Dar al-Affan.

[6] Izzuddin bin Abdul Salam, 1980, Qawa'id Al-Ahkam Fi Mashalih Al-Anam, 
Beirut, Darul Jail.

[7] Muhammad Jawad Mughniyah, 2012, Al-Fiqh 'Ala Al-Madzahib Al-Khamsah (Terjemahan Masyukur A.B) Jakarta, Lentera.

[8] Soerjono Soekanto, 1974, Beberapa Permasalahan Hukum Dalam Kerangka Pembangunan Indonesia, Jakarta, UI Press.

[9] Sudikno Mertokusumo, 1988, Mengenal Hukum (Suatu Pengantar), Yogyakarta, Liberty.

[10] Suratman, Dkk., 2019, Hukum \& Kebijakan Publik, Bandung, Refika. 